\title{
REPORT OF THE SECOND EASTERN EUROPEAN CONFERENCE ON CRYPTOCURRENCIES (4 MARCH 2019, BIAŁYSTOK, POLAND)
}

On March 4, 2019, at the Faculty of Law of the University of Bialystok took place the Second Eastern European Conference on Cryptocurrencies organized by the Scientific Circle of Financial Law, Scientific Circle of Commercial Law and Scientific Circle of Tax Law operating at the Faculty of Law of the University of Bialystok. The conference was covered by the Honorary Patronage of the Ministry of Science and Higher Education, Marshal of the Podlasie Voivodship Artur Kosicki, Podlasie Voivode Bohdan Paszkowski and the Rector of the University of Bialystok prof. dr hab. Robert W. Ciborowski. Among the Honorary Patrons of the event were also the Deputy Marshal of the Podlasie Voivodeship Stanisław Derehajło, the Temida 2 Publishing House and Euronet Norbert Saniewski sp. j., which enabled to show a machine digging cryptocurrency, i.e. the so-called cryptocurrency excavator.

The conference began at 9:00 in the Hall of the Faculty of Law and was opened by prof. zw. dr hab. Ewa Monika Guzik - Makaruk, Deputy Dean for Science of the Faculty of Law, and prof. dr hab. Eugeniusz Ruśkowski, head of the Department of Public Finance and Financial Law and the Supervisor of the Scientific Circle of Financial Law. After the presentation and welcome of the invited guests, the substantive part of the conference began, divided into expert panels led by dr Ewa Lotko and dr Urszula Zawadzka-Pąk from the Department of Public Finance and Financial Law, and doctoral and student panels led by Magdalena Olchanowska, Ewelina Marcińczyk and Hanna Deilidka - representatives of the Scientific Circle of Financial Law.
The lecture opening the conference "Using cryptocurrencies in money laundering" was given by dr hab. Wojciech Filipkowski, prof. UwB, representing the Department of Criminal Law and Criminology at the Faculty of Law, UwB. In his speech, prof. Filipkowski referred to threats resulting from the popularity of cryptocurrencies transformed into a tool for committing crimes.

Another speech at the expert panel of the conference was by dr hab. Sławomir Presnarowicz, prof. UwB from the Department of Public Finance and Financial Law at the Faculty of Law of the University of Bialystok, entitled "Cryptocurrencies in Poland in 2019 - selected tax aspects". The idea behind the presentation was to show this issue based on an outline of the changes that have occurred in recent months as a result of interest of tax administration in cryptocurrencies.

Then the next speaker was mgr Grzegorz Jarosiewicz, representing the Tax Department at the Faculty of Law, who delivered a lecture entitled "Legal regulations concerning taxation of virtual currencies trading". In his speech, mgr Jarosiewicz presented all issues raising questions about the tax treatment of cryptocurrencies.

Next lecture was given by prof. Olga Lutova from N.I. Lobachevsky State University in Nizhny Novgorod (Russia) "Cryptocurrencies in the Russian Federation", in which she presented the situation of virtual money in the Russian system.

Another speaker - prof. Aleksander Morozov (also from the N.I. Lobachevsky State University of in Nizhny 
Novgorod) - presented his speech entitled "Existing approaches to legal regulation of cryptocurrency taxation in the Russian jurisdiction", from which it was possible to draw differences between the Polish and Russian system of virtual money taxation.

Next lecture "Cryptocurrency: problematic aspects of legal regulation" delivered by prof. Imed Tsindeliani from the Russian Academy of Justice in Moscow focused on obstacles to recognise crypto-currency by the legislature.

Then a lecture entitled "Cryptocurrency and state sovereignty" was presented by prof. Dmitry Szczerbik from the Polotsk State University in Polotsk, in which he presented possible disturbances in the state relationship with the newly created type of coins.

Another speaker was also a representative of the Polotsk State University. Professor Aliaksej Radziuk delivered a lecture entitled "The Social Impact of Cryptocurrency Experiment in Belarus" thanks to which it was possible to learn how bitcoin influenced the Belarusian society and what were their first reactions to entering the crypto market.

The last speech of the expert panel was by prof. Ryma Kluczko (Yanka Kupala State University of Grodno) "Criminal legal assessment of crimes involving cryptocurrency". The lecture focused on the possible use of cryptocurrencies in the broadly defined crime, presenting the most serious threats associated with it.

The expert panel ended at 12:10, then the second part of the conference began, during which doctoral students gave their speeches.

The first presentation in this part was delivered by mgr Maksymilian Szal, a PhD student at the Department of Civil and Commercial Law at the Faculty of Law, entitled "Cryptocurrencies as the subject of contribution to a commercial company". Other $\mathrm{PhD}$ students who took part in the conference included representatives of universities from Poland and abroad:

- Masaryk University in Brno (Czech Republic) - mgr Richard Bartes ("Selected legal aspects of cryptocurrencies in the Czech Republic")

- Polotsk State University (Belarus) - mgr Viktoria Dorina ("International legal regulation of cryptocurrencies"), mgr Pavel Salauyou ("Legal regulation of Blockchain technology and cryptocurrency: the problem of choosing lawmaking strategies")

- University of Wroclaw - mgr Łukasz Cymbaluk ("Political implications of cryptocurrencies")
- Cardinal Stefan Wyszyński University in Warsaw mgr Sylwia Szutko ("Consequences of new taxation rules for cryptocurrencies and qualify income from virtual currency trading to income from cash capitals"), mgr Ida Jóźwiak ("Cryptocurrencies as the subject of regulations in the field of counteracting money laundering and terrorism financing")

- University of Warsaw - mgr Katarzyna Ziółkowska ("ICO and crypto-assets in the EU regulatory framework - conclusions from the position of the European Securities and Markets Authority published on January 9, 2019”), mgr Konrad Sukojaj ("Taxation of trading in cryptocurrencies with tax on goods and services")

- Maria Curie-Skłodowska University in Lublin mgr Maciej Błotnicki ("Selected aspects of the functioning of virtual currencies on the basis of applicable criminal law regulations - adequacy, or lack thereof in the proper protection of legal goods in the $21^{\text {st }}$ century?")

- The Jagiellonian University in Kraków - mgr Wiktor Podsiadło ("Taxation of virtual currencies, tax on natural persons")

- University of Bialystok - mgr Cezary Pachnik ("Cryptocurrency as an instrument for the pursuit of autonomy or independence of indigenous peoples and national minorities in the light of the principles of international law"), mgr Izabela Grens - Trykoszko ("Bitcoin as an object of property security"), mgr Paweł Szorc ("Regulations on protection of personal data as a barrier to the development of blockchain and cryptocurrency technologies"), mgr Katarzyna Jarnutowska ("Cryptocurrencies as an object of private law relations"), mgr Magdalena Anna Kropiwnicka ("What is bitcoin? Legal character of bitcoin"), mgr Justyna Omeljaniuk ("Cryptocurrencies as subject of crime"), mgr Paweł Czaplicki ("Initial Coin Offering - legal aspects of capital acquisition by entrepreneurs using digital currencies"), mgr Agnieszka Godlewska and mgr Paulina Grodzka ("Taxation of cryptocurrencies and tax honesty"), mgr Łukasz Presnarowicz ("Actions of the Office of Competition and Consumer Protection in the field of cryptocurrency").

The doctoral panel ended at 15:00 followed by a lunch break, which lasted until 16:00. Then a practical panel discussion started. 
The speeches ended at 17:00 and then a 10 minutes coffee break began. At 17:10 the student panel started, during which representatives of both foreign and Polish universities were also present:

- Polotsk State University (Belarus) - Palina Kavalchuk ("Using cryptocurrency in Belarus")

- Siedlce University of Natural Sciences and Humanities - Dominik Kowalczyk ("Cryptocurrencies and threats that they introduce to social security")

- Nicolaus Copernicus University in Torun - Paulina Wysocka ("Money laundering and cryptocurrencies"), Jakub Rolirad ("Cryptocurrencies as an excellent thesaurization of property or a financial pyramid?")

- University of Lodz - Agnieszka Sobierajska ("Legal aspects of tokens - civil law analysis including personal tokens")

- Maria Curie-Skłodowska University in Lublin - Piotr Jackiewicz, Dominika Gozdalska ("Legal and tax aspects of cryptocurrencies in the Republic of Poland")

- University of Warsaw - Ewa Tokarewicz ("Prudence or short-sightedness - about the approach of a Polish employer to cryptocurrency on the example of tax on civil law transactions"), Filip Sobociński ("Is the token equity issue a public offer?"), Kamil Węgliński ("Cryptocurrencies - groundbreaking technology of the Internet")
- Odessa (Ukraine) - Masenko Yaroslav (“EOS Blockchain 3.0")

- Minsk (Belarus) - Alina Bańkowskaja ("Cryptocurrencies: a role in the modern world"), Kiril Kozal ("Cryptocurrency and Bitcoin. Money of the new generation”), Daria Umanskaja ("Prospects for recognition and development of cryptocurrencies in European countries"), Julia Karazej ("Perspectives of using cryptocurrencies in the legal sphere")

- Turkey (Erasmus student at University of Białystok) - Abdullah Bahçe ("Big increase in interest in bitcoin in Turkey - the fall of the lira"), Onur Duran ("Currency crisis, and the introduction of the crypto-currency exchange"), Elif Sila Cesur ("Solutions for introducing cryptocurrencies”), Burhan Budak ("Abduction of cryptoblogs - forensic aspects of cryptocurrencies trading"), Barış Gökler ("Bitcoin vs. alcony - comparison")

- University of Bialystok - Bartłomiej Korolczuk ("Potential of the Blockchain Model")

After thanking all invited guests as well as all participants of the conference, the conference was closed at 20:40 by Magdalena Olchanowska, president of the Scientific Circle of Financial Law. 